\title{
The Trade Effects of a South Asian Customs Union: An Expository Study
}

\author{
M. AkHlaqur Rahman, Ayubur Rahman BHuYAN and \\ SADREL REZA*
}

\begin{abstract}
The paper estimates the static trade effects of a customs union comprising Bangladesh, India, Nepal, Pakistan and Sri Lanka. Although these effects are found to vary between countries, for the region as a whole the trade-creation effects appear to be greater than the trade-diversion effects. Despite their smallness, the direction of the change indicated by the static results seems encouraging to possible attempts at the formation of a customs union among South Asian countries.
\end{abstract}

The object of this article is to present a quantitative estimate of the static trade effects of a probable regional economic integration scheme in South Asia comprising Bangladesh, India, Nepal, Pakistan and Sri Lanka. The specific form of integration considered here is a customs union wherein all trade barriers within the union are abolished, but a common external tariff (CET) is imposed against the outsiders. This would lead to an increase in imports of the participating countries from each other, because buyers in each country would switch from the competing highcost domestic products to the cheaper imports from partner sources, resulting in a net increase in imports (trade creation). Also, imports from partners would substitute low-cost imports from non-members (trade diversion). The latter, however, would not cause any net increase in the total imports of member countries, since it would represent merely a switch in the country of origin. To make any estimate of trade effects meaningful these two elements have to be calculated separately. The net total change in the individual countries' imports from both within and outside the region are then easily deduced.

*Dr. Rahman is Professor of Economics at Jahangir Nagar University, and Dr. Bhuyan and Dr. Reza are Associate Professors of Economics at the University of Dacca. The present paper is based on parts of a recently completed research report on a probable South Asian Customs Union. Comments received from Professor Robert Triffin on an earlier draft of the paper helped in strengthening some of its arguments. Funds received from the External Resources Division, Ministry of Finance, Govt. of Bangladesh and the Ford Foundation are gratefully acknowledged. The authors themselves are, however, responsible for the opinions expressed and for any deficiency that may remain. 


\section{METHODOLOGY}

The magnitude of the effects of the elimination of tariffs on trade in a commodity following the establishment of a customs union will depend upon four major factors. They are:

(a) the height of the original tariff rates to be eliminated;

(b) the size of the fall in prices brought about by the abolition of tariffs;

(c) the responsiveness of the import demand to changes in price in the individual countries, i.e. the price elasticity of demand for imports; and

(d) the initial volume of imports from the partners, i.e. before the formation of the union.

The greater the magnitude of each of the above factors, the greater will be the increase in the total volume as well as value of imports.

Our analysis of the trade effects is based on a model recently constructed and applied by Bhuyan [5] to a similar study which represents an extension of the classic approach of Viner [27], formalized and modified by others ${ }^{1}$, to incorporate in it such changes so as to facilitate also the estimation of the effects of aligning the common external tariffs - an important aspect which has hitherto been ignored in the empirical literature. The model assumes that tariffs are the only barrier to trade; the price effects on trade are instantaneous; the production methods, factor supplies, and tastes remain unaltered; other induced changes on imports are non-existent; and the export supply of the union is infinitely elastic.

Without repeating the details of the Bhuyan model, we present here the following two basic equations which represent the process involved in calculating the trade effects of the proposed union:

$$
\Delta M_{i}=\sum_{i=1}^{m} e_{m}, i\left\{-\left(\frac{t_{i}}{1+t_{i}}\right) M_{u, i}\right\}+\sum_{i=1}^{m} e_{m}, i\left\{-\left(\frac{t_{i}-c_{i}}{1+t_{i}}\right) M_{v, i}\right\} \ldots
$$

$$
\mathrm{e}_{\mathrm{m}_{\mathrm{i}}}<0
$$

and

$$
\begin{gathered}
\Delta \mathrm{M}_{\mathrm{v}, \mathrm{i}}=\sum_{\mathrm{i}=1}^{\mathrm{m}}\left(\frac{\Delta \mathrm{M}_{\mathrm{i}}}{\mathrm{M}_{\mathrm{i}}}\right) \mathrm{M}_{\mathrm{v}, \mathrm{i}}-\sum_{\mathrm{i}=1}^{\mathrm{m}} \eta_{\mathrm{i}}\left\{-\left(\frac{\mathrm{t}_{\mathrm{i}}}{1+\mathrm{t}_{\mathrm{i}}}\right)-\left(-\frac{\mathrm{t}_{\mathrm{i}}-\mathrm{c}_{\mathrm{i}}}{1+\mathrm{t}_{\mathrm{i}}}\right)\right] \\
\frac{\mathrm{M}_{\mathrm{u}, \mathrm{i}} \mathrm{M}_{\mathrm{v}, \mathrm{i}}}{\mathrm{M}_{\mathrm{i}}}, \ldots(2), \eta_{\mathrm{i}}<0
\end{gathered}
$$

${ }^{1}$ Especially by Balassa [1], Hawkins [9], Hitiris [10], Janssen [12], Johnson [13], Kreinin [16], and Verdoon [28]. where

$$
\begin{aligned}
& \mathrm{M}_{\mathrm{i}}=\text { volume of imports of the ith commodity, } \\
& \mathrm{M}_{\mathrm{u}, \mathrm{i}}=\text { initial intra-regional import of the ith commodity, } \\
& \mathrm{M}_{\mathrm{v}, \mathrm{i}}=\text { initial extra-regional import of the ith commodity, } \\
& \mathrm{t} \quad=\text { initial tariff rates, } \\
& \mathrm{c} \quad=\text { rates of common external tariff, } \\
& \mathrm{e}_{\mathrm{m}} \quad=\text { price elasticity of import demand of a member concerned, and } \\
& \eta_{\mathrm{i}} \quad=\text { elasticity of substitution. }
\end{aligned}
$$

Equation (1) yields the direct price effects of a customs union on a member's total imports, derived as a result of the alteration of tariffs and, hence, of prices. ${ }^{2}$ The first term on the right hand side of the equation is always positive ${ }^{3}$ and will indicate the expected change in the member's imports from inside the union as a result of tariff elimination. The whole of this change can be said to constitute trade creation. The second term measures the expected change in the member's imports from outsiders as a result of the adjustment of the pre-union tariffs to the newly set up CET. This change may be positive or negative depending on whether there is a downward or upward adjustment of the pre-union tariffs to the level of the CET. If there is a downward adjustment of the pre-union tariffs, i.e. when $\mathrm{C}_{\mathrm{i}}<\mathrm{t}_{\mathrm{i}}$ and, hence, $\frac{t_{i}-c_{i}}{1+t_{i}}<0$, there will be an expansion of imports from outside the union (external trade creation). In the opposite case, when $c_{i}>t_{i}$ and, hence, $\frac{t_{i}-c_{i}}{1+t_{i}}>0$, the member's extra-area imports will decline.

Equation (1) provides a measure of the total import effects of tariff elimination which contains elements of both trade creation and trade diversion, but it does not show the full extent of trade diversion. It is equation (2) which gives a measure of the amount by which extra-regional imports of a member country will be substituted by intra-regional imports. This substitution effect, $\Delta \mathrm{M}_{\mathrm{v}, \mathrm{i} \text {, will indicate }}$ trade diversion whenever it turns out to be negative, and trade expansion with non. members whenever it turns out to be positive.

${ }^{2}$ This is based on the very simplifying assumption that price changes occur entirely due to changes in tariffs, which effectively rules out from our purview all non-tariff barriers such as quotas, exchange control and other restrictive trade practices.

${ }^{3}$ Because, by definition, $e_{m}$ is negative. 
Equations (1) and (2) thus constitute a complete model for estimating the total expected change in imports of member countries in a customs union and the extent of trade diversion in it resulting from the union. The advantage of this model lies in its simplicity and operational efficiency. It directly estimates the trade diversion effects, a knowledge of which is essential for assessing the desirability of an integra tion scheme. The residual, derived by subtracting the substitution effect from the total import effects, automatically determines the net change in the member's intraregional imports.

\section{DATA}

The estimation of the trade effects involves the use of data on tariffs, price elasticities, the elasticities of substitution, and intra- and extra-regional imports of the member countries. The import figures used are those of 1976 and are presented, along with the results, in the next section. A few words on each of the variables used in our model appear below.

\section{The Structure of Tariffs}

Table 1 sets out, at the SITC one-digit level ${ }^{4}$, the average nominal tariff rates $^{5}$ for each of the five South Asian Countries under consideration. The rates are weighted averages of rates on components within each broad group, the corresponding import values having been used as weights. The rates of CET have been computed by taking the weighted average rates of all country averages, where extra regional import of each country has been used as weights. ${ }^{6}$

\section{Price Elasticities of Import Demand}

The elasticity co-efficients for all five countries relating to the various commodity categories are presented in Table 2. The values for Bangladesh, India, Pakistan and Sri Lanka have been taken from Bhuyan [5]. In the case of Nepal, for which appropriate statistical data are not available, we have used Bangladesh's parameters as proxies, except with respect to the price elasticity of demand for SITC $0+1$ for which we have assumed a magnitude of unity. The reason for the former

${ }^{4}$ The one-digit SITC (Standard International Trade Classification) Sections are as follows: $0=$ Food and live animals; 1 = Beverages and tobacco; $2=$ Crude Materials, Inedibles, excluding fuels; $3=$ Mineral fuels and lubricants; $4=$ Animal and vegetable oils and fats; $5=$ Chemicals; $6=$ Basic manufactures; 7 = Machinery and transport equipetable oils and fats, 5 = Chemicals; goods; 9 = Goods not classified by kind. See [26].

${ }^{5}$ Ideally, it is the effective rates, rather than nominal rates, which should have been used or estimating the probable effects of tariff elimination on trade flows. However, because of lack of detailed information on effective tariff rates of all the five countries under study, we have to be content here with the use of only nominal rates in our computations.

${ }^{6}$ This is in keeping with the GATT requirement that the rates of CET of the union should not exceed the average of the pre-union tariff rates of member countries.
Table 1

Rates of Import Duty of South Asian Countries by SITC Groups, 1976

(in percent)

\begin{tabular}{ccccccc}
\hline $\begin{array}{c}\text { SITC } \\
\text { Groups }\end{array}$ & Bangladesh & India & Nepal & Pakistan & Sri Lanka & CET \\
\hline $0+1$ & 40 & 45 & 20 & 40 & 20 & 35 \\
2 & 45 & 40 & 7 & 26 & 14 & 30 \\
3 & 5 & 10 & 5 & 5 & 1 & 6 \\
4 & 45 & 55 & 5 & 30 & 30 & 30 \\
5 & 50 & 55 & 5 & 40 & 25 & 35 \\
$6+8$ & 75 & 70 & 7 & 85 & 20 & 60 \\
7 & 45 & 50 & 25 & 40 & 17 & 42 \\
\hline $0-9$ & 45 & 50 & 15 & 40 & 19 & 35 \\
\hline
\end{tabular}

Sources and Method: Computed by method as described in the text; for basic data see $[4 ; 11 ; 17 ; 20 ; 23]$.

Table 2

Price Elasticities of Import Demand of South Asian Countries

\begin{tabular}{clllll}
\hline $\begin{array}{c}\text { SITC } \\
\text { Groups }\end{array}$ & Bangladesh & India & Nepal & Pakistan & Sri Lanka \\
\hline $0+1$ & 0.591 & 0.500 & 1.000 & 1.623 & 0.390 \\
2 & 1.306 & 1.601 & 1.306 & 0.184 & 0.313 \\
3 & 0.895 & 1.331 & 0.895 & 0.0 & 0.313 \\
4 & 0.0 & 2.517 & 0.0 & 5.076 & 0.313 \\
5 & 0.969 & 0.742 & 0.969 & 1.657 & 0.313 \\
$6+8$ & 1.185 & 1.216 & 1.185 & 0.875 & 1.769 \\
7 & 0.756 & 0.893 & 0.756 & 1.139 & 0.635 \\
\hline
\end{tabular}

Source: See text. 
has been the structural similarities between the two countries: in 1978, the per capita GDP of Bangladesh and Nepal amounted to 84 and 108 U.S. dollars, respectively; the contributions of agriculture and manufactures to GDP amounted to 53.5 and 7.8 percent, respectively, in Bangladesh and 67.0 and 11.0 percent, respectively, in Nepal; in 1976, both the countries had similar trade/GDP ratios, e.g. about 19 percent [22]. The reason for the latter was the great dissimilarity between them in respect of the supply of food, the most important item in SITC $0+1$. For example, between 1975 and 1978, food import in Bangladesh, mostly under aid, was massive; and its relation to price changes, if any, was likely to be negligible. We, therefore, presume that a parameter higher than that of Bangladesh should be more appropriate. $^{7}$

\section{The Elasticity of Substitution}

Because of non-availability of relevant data on the volume and prices of imports of member countries from both within and outside the region, it has not been possible for us to estimate the elasticities of substitution for import into these countries. We had, therefore, to assume a certain magnitude for substitution elasticity based on a number of well-considered factors. ${ }^{8}$

Our choice of a particular magnitude has been guided by the accepted belief, based on certain empirical findings [8] , that the substitution elasticities are generally much higher than the import demand elasticities. This means that the elasticity of substitution for imports into a member country between partner and non-partner goods is likely to be higher than the average elasticity of demand for similar imports from member countries.

There are well known reasons for this being so. The elasticity of substitution between two sources of supply is influenced by, among other things, the extent of the substitutability of the two goods. Ceteris paribus, the greater the extent of substitutability, the greater is the elasticity of substitution likely to be. ${ }^{9}$ It is highly possible that most goods produced in South Asian Countries would be inferior substitutes for similar products of many non-union countries which would lower the elasticity of substitution of imports from the member countries and raise that of imports from outside the union. This, will however, partly be offset by the geographical proximity of partner countries, which creates the advantages of comparatively lower transport costs, in addition to those of relatively free and sheltered markets. Nevertheless, it may safely be presumed that extra-union imports in a member

${ }^{7}$ We believe that even if the magnitude were slightly different from the one chosen by us, it would not have affected the results to any significant extent.

${ }^{8}$ This is a fairly common practice. In similar statistical exercises in the past, a number of authors made use of such assumptions on the magnitude of the elasticity of substitution of imports between two sources of supplies. See, for example, $[1 ; 9 ; 15]$.

${ }^{9}$ For example, Banerjee [2] found the elasticity of substitution relating to the import of cotton piece-goods in India from U. K. and Japan to be as high as $(\rightarrow) 8.64$ country will either be competitively superior to or highly differentiated from the competing intra-union imports.

Considering all these factors, we have assumed a magnitude of $(-) 2.5$ for substitution elasticity for all countries and for all commodity groups. This would seem to be a conservative figure, although it is two-and-a-half times larger than the average import demand elasticity of South Asia.

\section{THE RESULTS AND INTERPRETATION}

The estimated trade effects of a South Asian Customs Union are detailed in Tables 3 through 7 for the five participating countries, and summarized for the region as a whole in Tables 8 through 10. The welfare implications of the union for the member countries are shown in Table 11.

\section{Trade Effects on Individual Countries}

\section{Bangladesh}

The estimated increase in Bangladesh's intra-regional import as a result of the union is $\$ 33.5$ million, i.e. about 48 percent of the existing level of her intraregional imports. This increase is seen to take place largely in manufactures and partly in raw materials. The structure of CET, as conceived in this study, leads to a downward adjustment of Bangladesh's tariff level, and, hence, no trade diversion is expected to occur. On the other hand, because of the realignment of the tariff level downward, there is some evidence of trade expansion with outsiders. This increase is more than half of the increase in intra-regional imports and about a third of the increase in total imports.

The estimated rise in total imports of Bangladesh is \$ 51 million, i.e. about 6 percent over the pre-existing level of imports. The country's intra-regional imports as percentage of total imports are expected to go up from 7.8 percent in the pre-union period to about 13 percent immediately after the union.

India

The predicted increase in India's imports from within the region is $\$ 31.5$ million, which is an increase of about 64 percent in her intra-union imports over the base year. This increase will be concentrated mostly in primary products, i.e. SITC 0,1 and 2. This is not at all surprising because at the current level of India's industrial development relative to the other countries of the region, there is only limited scope for the country to import manufactured products from the other partners.

The estimated rise in India's total imports amounts to $\$ 408.2$ million, which is 5.8 percent of her initial total imports. The results do not show any trade diversion for India's imports. On the contrary, the extra-regional imports are expected to 
Estimated Change in Bangladesh's Imports in a South Asian Customs Union (1976 Prices in Million U.S. dollars)

\begin{tabular}{|c|c|c|c|c|c|c|c|c|c|c|}
\hline \multirow{3}{*}{$\begin{array}{l}\text { SITC } \\
\text { Groups }\end{array}$} & \multicolumn{3}{|c|}{1976 Imports } & \multirow{3}{*}{$\left.\frac{t_{i}}{1+t_{i}}\right)$} & \multirow{3}{*}{$\left(-\frac{t_{i}-c_{i}}{1+t_{i}}\right)$} & \multicolumn{3}{|c|}{ Changes in Imports $\left(\Delta \mathrm{M}_{\mathrm{i}}\right)$} & \multirow{3}{*}{$\begin{array}{l}\text { Substi- } \\
\text { tution } \\
\text { Effect } \\
\left(\Delta \mathrm{M}_{\mathrm{v}, \mathrm{i}}\right)\end{array}$} & \multirow{3}{*}{$\begin{array}{c}\text { Total Change } \\
\text { in Imports } \\
\text { from union } \\
\text { sources } \\
\left(\Delta \mathrm{M}_{\mathrm{u}, \mathrm{i}}\right) \\
(10) \\
=(8)-(9)\end{array}$} \\
\hline & \multirow{2}{*}{$\begin{array}{l}\text { Intra- } \\
\text { regional } \\
\left(\mathrm{M}_{\mathrm{u}, \mathrm{i}}\right)\end{array}$} & \multirow{2}{*}{$\begin{array}{l}\text { Extra } \\
\text { regional } \\
\left(\mathrm{M}_{\mathrm{v}, \mathrm{i}}\right)\end{array}$} & \multirow[b]{2}{*}{$\begin{array}{l}\text { Total } \\
\left(\mathrm{M}_{\mathrm{i}}\right) \\
\\
\\
(3) \\
=(1)+ \\
(2)\end{array}$} & & & \multicolumn{2}{|c|}{ Direct Effect of } & \multirow[b]{2}{*}{$\begin{array}{c}\text { Total } \\
\\
\quad(8) \\
=(6)+ \\
\quad(7)\end{array}$} & & \\
\hline & & & & & & $\begin{array}{l}\text { Intra- } \\
\text { regional } \\
\text { tariff } \\
\text { elimina- } \\
\text { tion } \\
(6)\end{array}$ & $\begin{array}{l}\text { Adjust- } \\
\text { ment of } \\
\text { tariffs } \\
\text { to CET } \\
\text { (7) }\end{array}$ & & & \\
\hline $0+1$ & 4.47 & 181.85 & 186.32 & -0.2857 & -0.0357 & 0.75 & 3.84 & 4.59 & 1.76 & 2.83 \\
\hline 2 & 8.28 & 73.24 & 81.52 & -0.3103 & -0.1034 & 3.36 & 9.89 & 13.25 & 8.05 & 5.20 \\
\hline 3 & 28.71 & 254.40 & 283.11 & -0.0476 & -0.0095 & 1.22 & 2.16 & 3.38 & 0.58 & 2.80 \\
\hline 4 & 1.51 & 65.38 & 66.89 & -0.3103 & -0.1034 & 0.00 & 0.00 & 0.00 & -0.76 & 0.76 \\
\hline 5 & 2.66 & 79.24 & 81.90 & -0.3333 & -0.1000 & 0.86 & 7.58 & 8.44 & 6.67 & 1.77 \\
\hline $6+8$ & 21.28 & 88.05 & 109.33 & -0.4286 & -0.0857 & 10.81 & 8.94 & 19.75 & 1.22 & 18.53 \\
\hline 7 & 2.19 & 70.80 & 72.99 & -0.3103 & -0.0207 & 0.51 & 1.11 & 1.62 & 0.03 & 1.59 \\
\hline Total & 69.10 & 812.96 & 882.06 & - & - & 17.51 & 33.52 & 51.03 & 17.55 & 33.48 \\
\hline
\end{tabular}

Sources and Method: Own calculations based on method described in the text; for basic data see $[3,6,18,21,26]$.

Table 4

Estimated Change in India's Imports in a South Asian Customs Union (1976 Prices in Million \$)

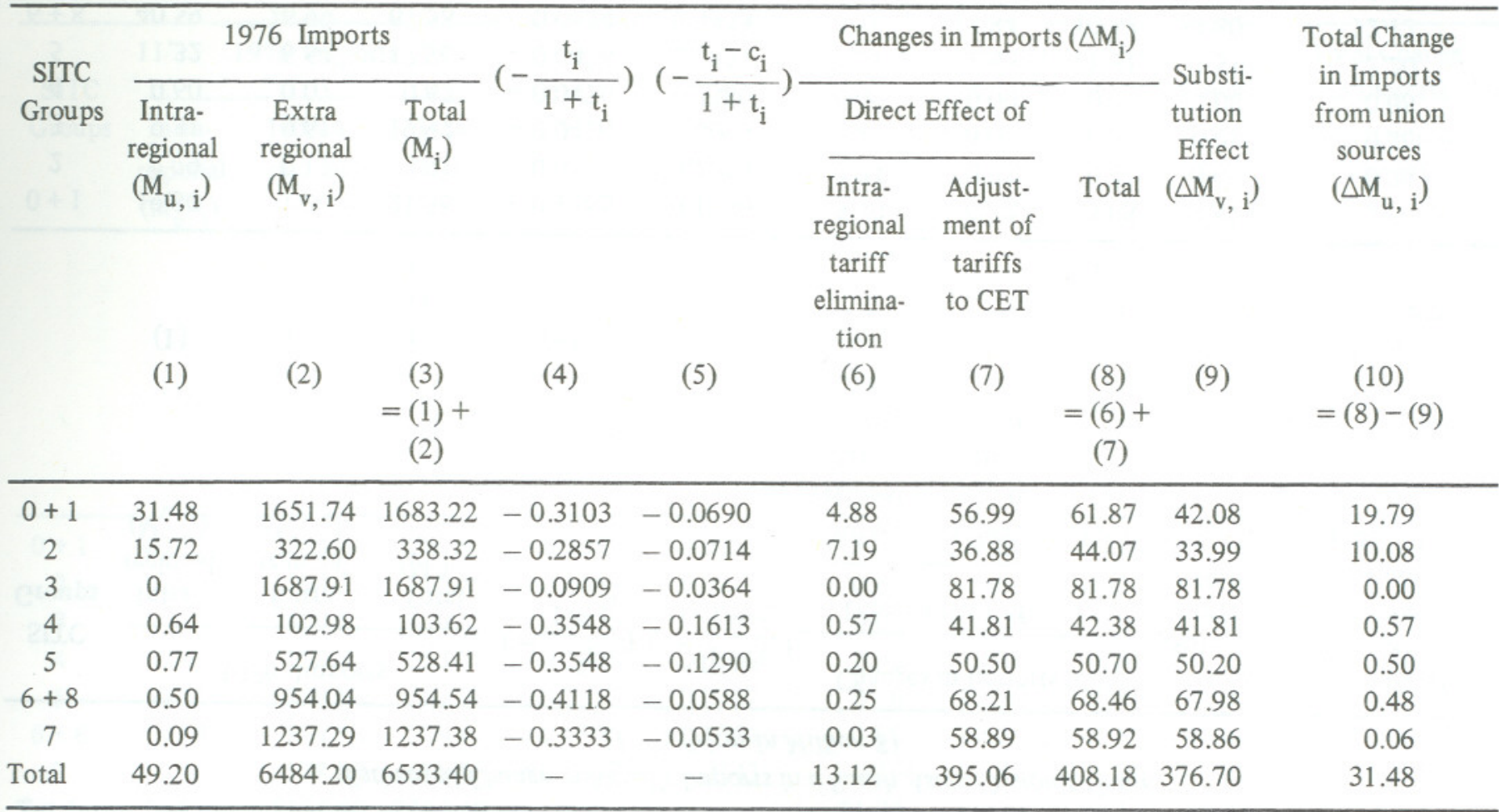

Sources and Method: Own calculations based on method described in the text; for basic data the sources are same as in Table 3 . 
Estimated Change in Nepal's Imports in a South Asian Customs Union (1976 Prices in Million \$)

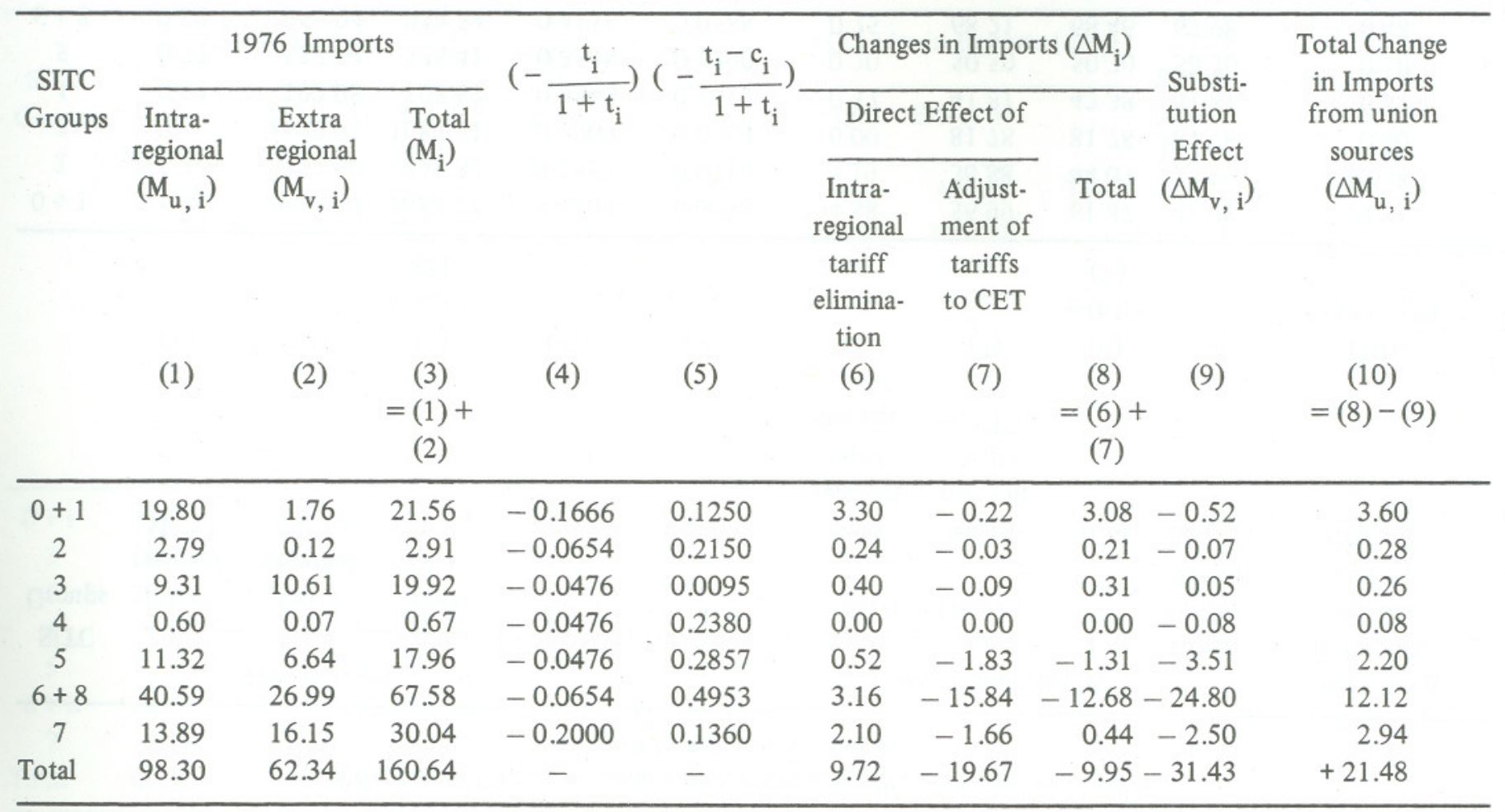

Sources and Method: Own calculations based on method described in the text; for basic data the sources are same as in Table 3 .

Table 6

Estimated Change in Pakistan's Imports in a South Asian Customs Union (1976 Prices in Million \$)

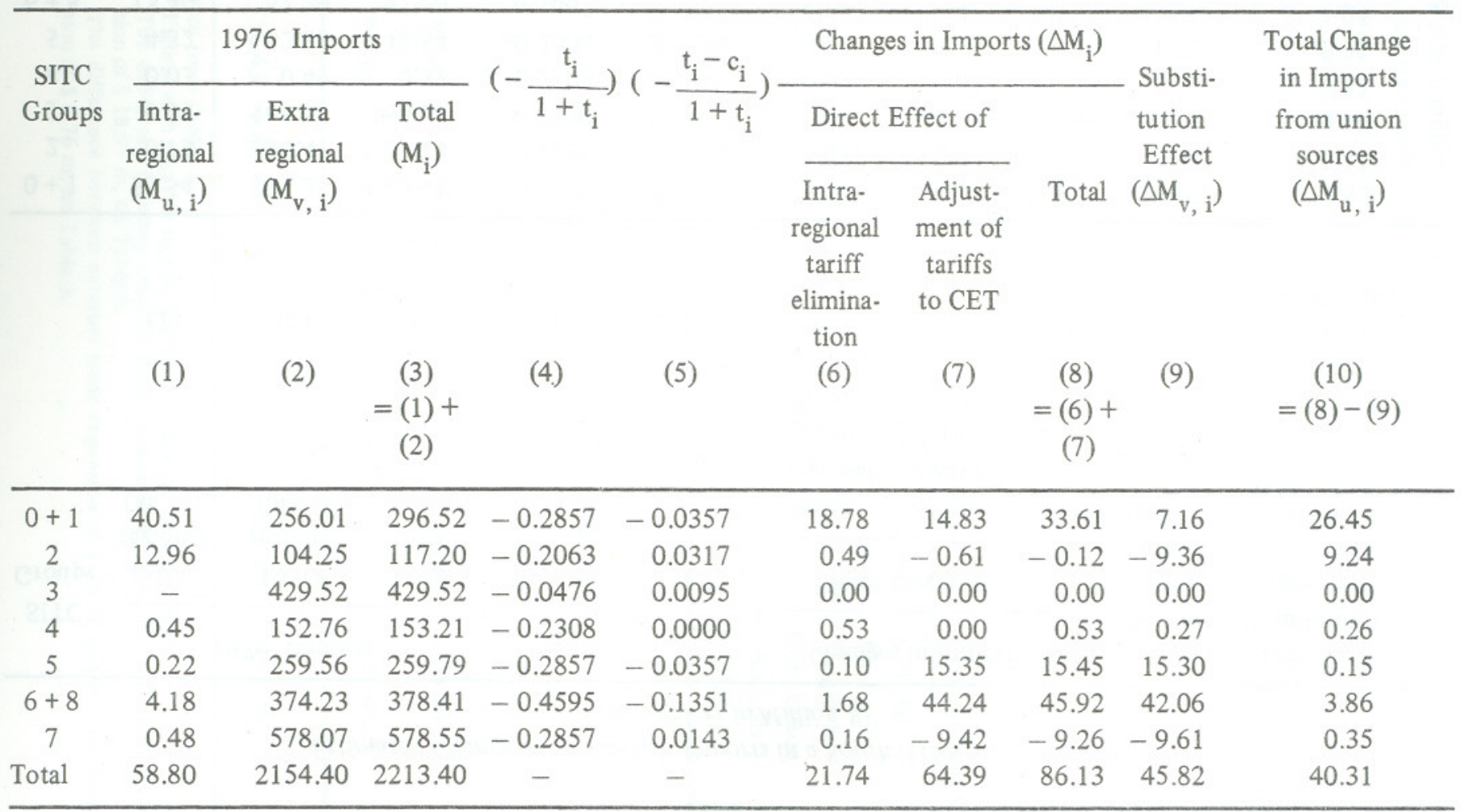




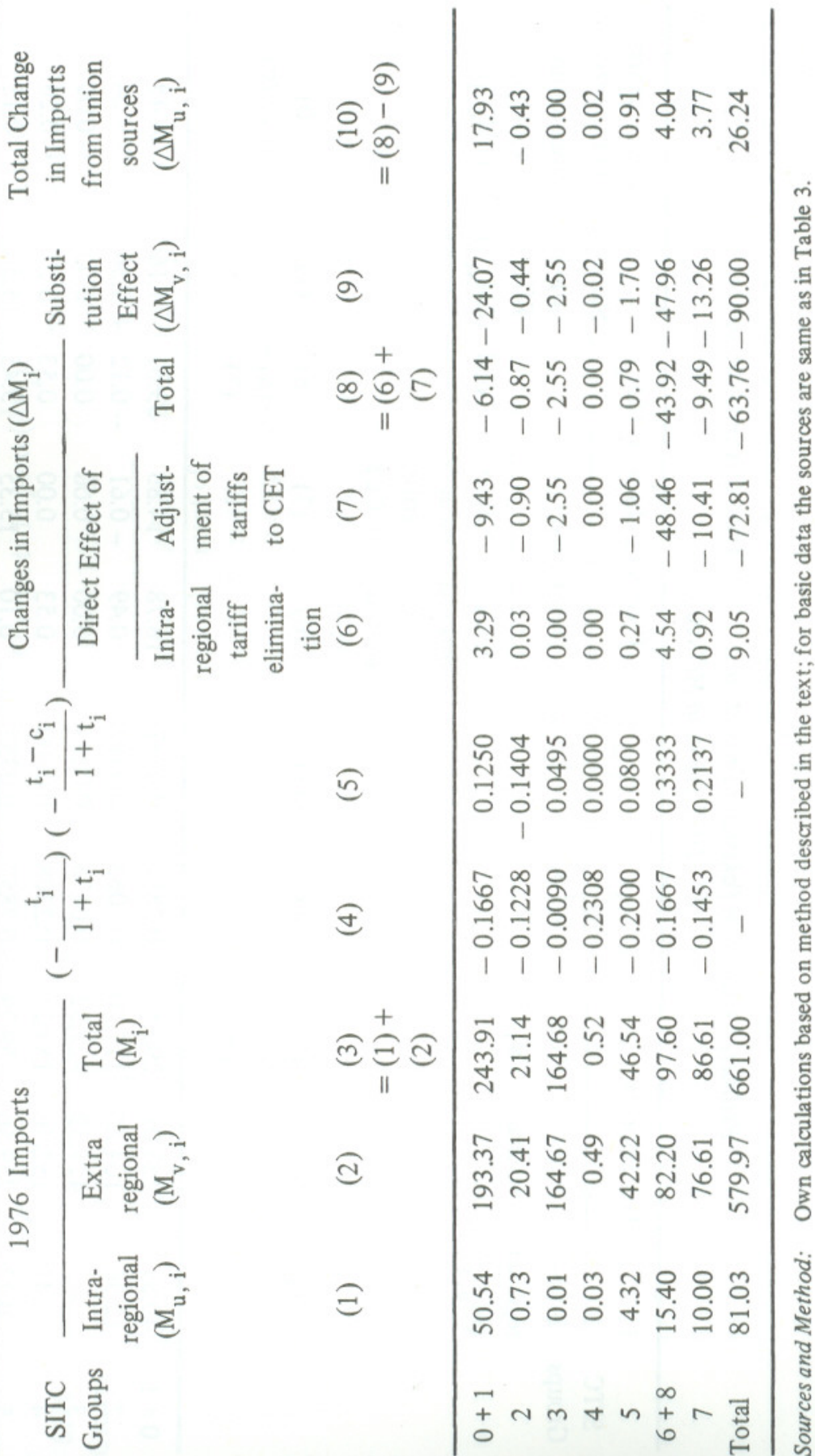

increase by $\$ 376.7$ million, i.e. by 5.8 percent over the initial level of such imports. However, in contrast with the large percentage increase in India's intra-regional imports, the increase in her total imports after the union is seen to be very small. This is due to the fact that intra-regional imports constituted a very small proportion of the country's total trade, and, hence, even a very large percentage increase in her intra-regional imports is unlikely to bring about any notable increase in her total imports.

Table 8

Estimated Change in Imports in South Asian Countries After Union: Summary

(in million \$)

\begin{tabular}{|c|c|c|c|c|c|c|}
\hline \multirow[b]{2}{*}{$\begin{array}{l}\text { Countries/ } \\
\text { Region }\end{array}$} & \multicolumn{3}{|c|}{ Import 1976} & \multirow{2}{*}{$\begin{array}{c}\text { Change in } \\
\text { total } \\
\text { import } \\
(\triangle \mathrm{M})\end{array}$} & \multirow{2}{*}{$\begin{array}{l}\text { Substi- } \\
\text { tution } \\
\text { Effect }^{a} \\
\left(\Delta M_{v}\right)\end{array}$} & \multirow{2}{*}{$\begin{array}{l}\text { Total } \\
\text { Change in } \\
\text { Imports } \\
\text { from Union } \\
\text { Sources } \\
\left(\Delta \mathrm{M}_{\mathrm{u}}\right)\end{array}$} \\
\hline & $\begin{array}{c}\text { Intra- } \\
\text { regio- } \\
\text { nal } \\
\left(\mathrm{M}_{\mathrm{u}}\right)\end{array}$ & $\begin{array}{l}\text { Extra- } \\
\text { regional } \\
\left(\mathrm{M}_{\mathrm{v}}\right)\end{array}$ & $\begin{array}{c}\text { Total } \\
\text { (M) }\end{array}$ & & & \\
\hline India & 49.20 & 6484.20 & 6533.40 & 408.18 & 376.70 & 31.48 \\
\hline Pakistan & 58.80 & 2154.40 & 2213.20 & 86.13 & $45.82^{b}$ & 40.31 \\
\hline Bangladesh & 69.10 & 812.96 & 882.06 & 51.03 & $17.55^{c}$ & 33.48 \\
\hline Sri Lanka & 81.03 & 579.97 & 661.00 & -) 63.76 & (-) 90.00 & 26.24 \\
\hline Nepal & 98.30 & 62.34 & 160.64 & (-) 9.95 & $(-) 31.43$ & 21.48 \\
\hline
\end{tabular}

Total:

$\begin{array}{llllll}\text { Region } \quad 356.43 & 10093.87 & 10450.30 & 471.63 & 318.64 & 152.99\end{array}$

Sources: Derived from Tables $3-7$.

Notes: (a) Figures with negative sign in this column indicate trade diversion.

(b) The difference between external trade expansion of $\$ 64.79 \mathrm{~m}$ and trade diversion of $\$ 18.97 \mathrm{~m} ;$ see Table 6 .

(c) The difference between external trade expansion of $\$ 18.31 \mathrm{~m}$ and trade diversion of $\$ 0.76 \mathrm{~m}$; see Table 3 . 
Table 9

Estimated Changes in Imports in South Asian Countries After Union

(in percent)

\begin{tabular}{lccc}
\hline $\begin{array}{c}\text { Countries/ } \\
\text { Region }\end{array}$ & $\begin{array}{c}\text { Intra-regional } \\
\left(\Delta \mathrm{M}_{\mathrm{u}} / \mathrm{M}_{\mathrm{u}}\right)\end{array}$ & $\begin{array}{c}\text { Extra-regional } \\
\left(\Delta \mathrm{M}_{\mathrm{v}} / \mathrm{M}_{\mathrm{v}}\right)\end{array}$ & $\begin{array}{c}\text { Total } \\
(\Delta \mathrm{M} / \mathrm{M})\end{array}$ \\
\hline India & 64.0 & 5.8 & 6.2 \\
Pakistan & 68.5 & 2.1 & 3.9 \\
Bangladesh & 48.4 & $(-) 15.5$ & $(-) 9.6$ \\
Sri Lanka & 32.4 & $(-) 50.4$ & $(-) 6.2$ \\
Nepal & 21.8 & 3.2 & 4.5 \\
\hline Total: Region & 42.9 & & 5.2 \\
\hline
\end{tabular}

Source: $\quad$ Derived from Table 8

Nepal

Nepal's existing tariff rates are the lowest among the five South Asian Countries, and the height of the CET that will emerge after the union will therefore invariably be higher than her pre-union tariff rates. As a result, the increase in imports from the region due to tariff withdrawal is likely to be relatively small. Thus, imports from intra-regional sources are likely to rise by $\$ 21.5$ million, i.e. about 21 percent of initial intra-regional imports. The estimates suggest that the share of the region in the country's total imports, which was 61.2 percent before the union, will increase to 65.2 percent immediately after the union. In contrast to the intra-regional trade changes, the establishment of the CET at a higher level is expected to lead to a substantial amount of trade diversion from extra-regional sources. The estimates here show that a customs union in South Asia will lead to a trade diversion for Nepal amounting to $\$ 31.4$ million which is about one-half of the country's extra-regional imports and about a fifth of her total imports.
Table 10

Share of Intra-regional Import in Total Import of South Asian Countries Before and After Union

(in percent)

\begin{tabular}{ccc}
\hline Countries/Region & Pre-Union & Post-Union \\
\hline India & 0.75 & 6.59 \\
Pakistan & 2.66 & 6.30 \\
Bangladesh & 7.83 & 12.87 \\
Sri Lanka & 12.26 & 13.57 \\
Nepal & 61.19 & 65.23 \\
\hline Total: Region & 3.4 & 4.7 \\
\hline Source: & Derived from Table 8. &
\end{tabular}

\section{Pakistan}

Pakistan's intra-regional imports are expected to increase by $\$ 40.3$ million, i.e. by 68 percent of the initial intra-regional imports. The extent of trade diversion from outside sources is 47 percent of the increase in intra-regional imports, i.e. about $\$ 19.00$ million. The categories in which trade diversion is seen to take place are crude materials and machinery and transport equipment. There will, however, occur a large amount of trade expansion, totalling over $\$ 64$ million, with non-union sources (external trade creation), which more than compensates for the loss from trade diversion. This expansion of trade with outsiders is the result of a downward adjustment of Pakistan's national tariffs to the level of the CET.

The change in the country's total imports is estimated at $\$ 86.1$ million, or only 3.9 percent of her pre-union imports. Over a half of this increase is found to lie in the imports of manufactures and another 40 percent in food items. The region's share in Pakistan's total imports will rise from 2.66 percent in the pre-union period to 6.3 percent immediately after the union. 
Table 11

Estimated Welfare Gains or Losses of a South Asian Customs Union

\begin{tabular}{ccc}
\hline Countries/Region & Welfare gain/loss & Percentage of 1976 \\
& (in million \$) & GNP \\
\hline
\end{tabular}

\section{Bangladesh}

India

Nepal

$$
(-) 0.2
$$

Pakistan

$$
26.8
$$

Sri Lanka

$$
(-) 13.7
$$

Total: Region

81.6

0.07

Sources: For tariff rates see table 1 ; for $\triangle \mathrm{M}$ see table 8 ; the GNP figures have been taken from [29].

Method: Assuming linear and downward-sloping demand functions and linear and upward sloping supply functions the estimates are made, in a partial equilibrium framework with the help of the equation: $G=1 / 2\left(\frac{t}{1+t}\right) \Delta M$, where $G=$ Welfare gains; $t=$ the rate of tariffs; and $\Delta \mathrm{M}=$ the estimated change in imports. For details on method see $[1,14]$.

\section{Sri Lanka}

A customs union is likely to lead to an increase in Sri Lanka's intra-regional imports by $\$ 26.2$ million. This increase is 32.4 percent of the initial level of her imports from within the region and nearly 4 percent of her total imports.

However, a customs union will cause a decrease in Sri Lanka's total imports by $\$ 63.8$ million, i.e. by about 9.6 percent of her initial imports. Such a decline may be ascribed to the following two factors: (i) the pre-union tariff level of Sri Lanka was low relative to the other countries of the region, and, hence, the direct price effect of intra-regional tariff elimination on imports from the region has been found to be as small as only $\$ 9.0$ million; and (ii) because of the setting up of the CET at a level higher than the country's pre-union tariff rates, imports from outside the region have also fallen. It is to be noted that the higher CET leads to a trade diversion for
Sri Lanka from outside sources by an amount of $\$ 90.0$ million, and this diversion is about 15.5 percent of the country's extra-regional imports, or about 14 percent of her total imports.

\section{Trade Effects for the Whole Region}

For the South Asian region as a whole, the estimated increase in intra-regional imports is $\$ 152.99$ million. This increase is about 43 percent of the pre-union intra-regional imports, which is expected to cause the share of intra-regional trade in the region to rise from 3.4 percent in 1976 to 4.7 percent immediately after the union. In contrast, the extent of trade diversion from outside sources is about $\$ 141$ million. All the same, a customs union in the region, on balance, may be considered trade-creating, since there occurs a large expansion of extra-regional trade, amounting to $\$ 459.8$ million, which is more than three times the estimated trade diversion.

The magnitude of trade diversion derived in our estimates, it has to be conceded, might have been strongly influenced by the restrictive scope of our analysis, particularly its static character, and the assumption of an average external tariff. Due to the essentially static character of the analysis (which assumes unchanged level of productivity and output), our results depict only the primary effects of integration, completely neglecting the whole range of secondary effects. If these secondary effects are taken into account, one might expect that with changes in the pattern of trade, overall productivity in member countries would rise, bringing with it a greater demand for imports from outside the region. For this reason, the trade-creating and the trade-diverting impacts of regional integration cannot be fully appraised by looking at the initial pattern of trade concession alone [24]. Indirect effects of integration should also be taken into account.

\section{Estimated Welfare Gains}

The welfare gains or losses due to the reallocation of resources after the formation of the customs union are derived from the estimated import effects of the integration scheme. The welfare effects are simply the excess of benefits in the form of consumers' surplus over the sum of losses to the domestic import-competing industry (producers' surplus) and the tariff revenue to the government. The estimated welfare effects in this study are quite small, and are in common with the results obtained in all previous empirical studies on actual or hypothetical integration schemes. ${ }^{10}$ For example, in percentage terms, the highest gains accrue to Pakistan, which is, however, only about 0.22 percent of her GNP, and the second highest gains accruing to Bangladesh amount to 0.10 percent of her GNP. The region as a whole

\footnotetext{
${ }^{10}$ See [5] and references cited therein.
} 
will derive welfare gains amounting to as low as 0.07 percent of the total regional income.

\section{CONCLUDING OBSERVATIONS}

\section{Conclusions}

The estimation of national gains and losses resulting from the formation of a union have important policy implications, especially with regard to the equitable distribution of benefits among the partners. They not only provide an opportunity for ascertaining any possible set-back that particular members might encounter in the process of their development through participation in it, but are also helpful in adopting suitable measures for off-setting such set-back, such as compensatory economic assistance to affected partner(s) and/or elongation of the period of transition in the process of the removal of trade barriers. Note, however, that the question of the equitable distribution of benefits, though very important, must not be overemphasized because, in the first place, undue concern about it might lead to unending negotiations and, in the second place, even if the sharing cannot be made ideally equitable, all partners might still benefit from an 'expected increase in non-zero sum game'.

\section{Further Observations}

The results obtained in the present study suffer from certain limitations which are inherent in the model itself, because of the assumptions behind it. First, the elasticity estimates are vitiated by the failure of the model to make appropriate allowance for the presence of quantitative restrictions on imports. Secondly, the high degree of aggregation in the commodity groups, in which both high-elasticity and low-elasticity products are lumped together, constrains the predictive effectiveness of the model. Thirdly, the model considers the once-for-all reallocational effects and ignores the long-run dynamic effects of economies of scales, and other benefits that may accrue from market enlargement and competition consequent upon the formation of a customs union. ${ }^{11}$ Nonetheless, let it be asserted that one would find the model a comparatively more convenient as well as efficient tool for analysing the static effects of a customs union. Furthermore, the static results, though quantitatively less impressive, are qualitatively highly significant since the direction of change indicated by them is undoubtedly encouraging to possible attempts at the formation of a customs union among the South Asian Countries.

\footnotetext{
${ }^{11}$ The argument for the formation of a customs union would be much stronger if one could also examine its dynamic consequences. These effects are not, however, easily amenable to quantitative estimation. Nevertheless, fairly encouraging results have been obtained by the present authors in their evaluation of some of the likely dynamic gains of a South Asian integration scheme, especially in matters of the scale effects of market expansion following
} union[22]

\section{REFERENCES}

1. Balassa, B. Trade Liberalization in Industrial Countries. New York: McGraw-Hill Book. Co. 1967. Ch. 4.

2. Banerjee, H. "Elasticities of Substitution for Indian Imports". Artha Vijnana. Vol. 1, No.4. December 1959.

3. Bangladesh Bank. Annual Import Payments, 1977-78. Dacca. 1979.

4. Bangladesh. Ministry of Finance. Bangladesh Customs, Excise and Sales Tax Tariff. Dacca. 1976.

5. Bhuyan, A. R. Economic Integration in South Asia: An Exploratory Study. Dacca: Dacca University Publication. 1979.

6. Central Bank of Ceylon. Annual Report, 1978. Colombo. 1979.

7. Grubel, H. G. "Inter-Industry Specialization and the Pattern of Trade". Canadian Journal of Economics and Political Science. Vol. 33. 1967.

8. Herberger, A. C. "Some Evidence on the International Price Mechanism". Journal of Political Economy. December 1957.

9. Hawkins, R. G. "The Economic Impact on the United States of a U. K. Canada - U. S. Free Trade Association". In Thomas M. Franck and Edward Weisband (eds.), A Free Trade Association. London: University of London Press. 1970.

10. Hitiris, T. Trade Effects of Economic Association with the Common Market: the Case of Greece. New York: Praeger. 1972.

11. Jain, R. K. Customs Tariff of India. 2nd ed. New Delhi: Central Law Office 1979.

12. Janssen, L. R. Free Trade, Protection and Customs Union. Leiden: Stenfert Kroese. 1961.

13. Johnson, H. G. "The Gains from Freer Trade with Europe: An Estimate". Manchester School. September 1958.

14. Johnson, H. G. "The Cost of Protection and the Scientific Tariff". Journal of Political Economy. August 1960.

15. Krause, L. B. "The European Economic Community and the United States Balance of Payments". In W. S. Salant (ed.), The United States Balance of Payments in 1968. Washington: The Brookings Institution. 1963.

16. Kreinin, M. E. "Effects of an Atlantic Free Trade Area on the American Economy”. Southern Economic Journal. July 1966

17. Nepal. Ministry of Finance. Customs Tariff, 1978- 79. Kathmandu. 1979.

18. Nepal Rastra Bank. Quarterly Economic Bulletin. Vol. X, No. 4, 1976 and Vol. XII, Nos. 1-2. 1978.

19. Orcutt, G. "Measurement of Price Elasticities in International Trade". Review of Economics and Statistics. May 1950.

20. Pakistan. Ministry of Finance. Pakistan Customs Tariff. 11 th ed. Islamabad. 1979. 
21. Pakistan. Statistics Division. Pakistan Statistical Yearbook, 1978. Karachi. 1979.

22. Rahman, M. A., A. R. Bhuyan, and S. A. L. Reza. A Customs Union in South Asia: Prospects and Problems. Dacca. Government of Bangladesh, Ministry of Finance: External Resources Division. June 1980.

23. Sri Lanka. Ministry of Plan Implementation. Department of Census and Statistics. Statistical Abstract of the Democratic Socialist Republic of Sri Lanka. Colombo. 1977.

24. Triffin, R. "The Size of the Nation and Its Vulnerability to Economic Nationalism". In E.A.G. Robinson (ed.), Economic Consequences of the Size of Nations. London: Macmillan. 1960.

25. UN. Foreign Trade Statistics of Asia and the Pacific. New York. 1976.

26. UN Statistical Office. Standard International Trade Classification Revised. Statistical Paper Series M, No. 34. New York. 1961.

27. Viner, J. The Customs Union Issue. New York: Carnegie Endowment for International Peace. 1950.

28. Verdoorn, P. J. "A Customs Union for Western Europe: Advantages and Feasibility". World Politics. Vol. 6.1954.

29. World Bank. World Development Report, 1978. Washington, D. C. 1979. 